Revistade
Economild
Contemporâned

\title{
MR. KEYNES AND THE ENVIRONMENT: TROPICAL DEFORESTATION AND THE CONCEPT OF USER COST
}

\author{
Carlos Eduardo Frickmann Young ${ }^{a}$ \\ aProfessor at the Institute of Economics, Federal University of Rio de Janeiro (IE/UFRJ).
}

Manuscript received on 2015/10/23 and accepted for publication on 2018/03/12.

\begin{abstract}
Keynes' General Theory has been a major source of inspiration in almost all areas of economics. However, it has been largely ignored in the environmental economics debate, characterized by a complete dominance of orthodox, neoclassical models. This is the case of tropical deforestation: the existing models that analyze the economic motivations that fuel the land clearing process use unrealistic assumptions and optimal control models that provide misleading results andincorrect policy recommendations. The objective of this paper is to present an alternative perspective for the problem, based on Keynes' definition of income and user cost. A simple theoretical model is used to describe the importance of land speculation in the capital component, thus affecting the land clearing decision. Economic policies have an important influence in this process, and consistent public policies aiming at controlling deforestation should consider these effects as well as the conventional issues that are addressed by environmental regulators.
\end{abstract}

KEYWORDS: deforestation; tropical forests; user cost; Keynes.

JEL CODES: E12; O13; Q15. 


\section{O SR. KEYNES E O MEIO AMBIENTE: DESMATAMENTO TROPICAL E O CUSTO DE USO}

RESUMO: A Teoria Geral de Keynes tem sido uma importante fonte de inspiração em quase todas as áreas da economia. No entanto, tem sido amplamente ignorado no debate sobre economia ambiental, caracterizado por um domínio completo dos modelos ortodoxos neoclássicos. Este é o caso do desmatamento tropical: os modelos existentes que analisam as motivações econômicas que alimentam o processo de remoção de terras usam hipóteses irreais e modelos de controle ótimo que fornecem resultados enganosos e recomendações de políticas incorretas. O objetivo deste artigo é apresentar uma perspectiva alternativa para o problema, com base na definição de renda e custo do uso de Keynes. Um modelo teórico simples é usado para descrever a importância da especulação de terras no componente de capital, afetando assim a decisão de desmatamento. As políticas econômicas exercem uma influência importante nesse processo, e políticas públicas consistentes para controlar o desmatamento devem considerar esses efeitos tanto quanto as questões convencionais abordadas pelos reguladores ambientais.

PALAVRAS-CHAVE: desmatamento; florestas tropicais; custo de uso; Keynes. 


\section{INTRODUCTION ${ }^{1}$}

Tropical deforestation is increasingly regarded as one of the most important environmental problems in developing countries. Nevertheless, this subject has remained a 'no go zone' for the heterodox economics literature. Almost all of the environmental economics literature dealing with tropical deforestation has a strong neoclassical background, implying very unrealistic assumptions in the analysis. For example, well defined land property rights are considered in order to allow optimal control modeling (for example, HARTWICK, 1992), even though this is the exception, rather than the rule, in the context of tropical developing countries.

Because of that, the speculative behavior that characterizes land accumulation in the agricultural frontier areas cannot be incorporated in the analysis. As many authors have already emphasized (YOUNG 1997, 2001; SCHNEIDER, 1994; OZÓRIO DE ALMEIDA and CAMPARI, 1996), the process of occupation of marginal forest land in the agricultural frontier is a transition situation in which privately owned property rights are being defined by the land clearing process. Only after this process, long term measures, such as soil conservation, become financially attractive to farmers (as explained by the conventional literature on the issue). But this crucial feature of the process remains unexplored by the orthodox, mainstream models that deal with the subject.

The objective of this paper is to fulfill this gap, by presenting a model of deforestation as a response to land accumulation motivated by land price speculation. Moreover, it is a pioneer attempt to use a very important Keynesian concept, the user cost, as an analytical tool to understand farmers' decisions concerning land clearing. The model has been originally designed to explain deforestation in the Brazilian Amazon (YOUNG, 1997), but there are no major problems in extending its use in other Latin American countries. Associated questions are: in which circumstances this process is limited from an economic perspective; what is the role of economic policies in the establishment (or not) of such a limitation; and the reason why better off farmers do not go themselves to the frontier and establish claims on quasi-open access land.

\footnotetext{
1 This article is partly based on the author's PhD Dissertation "Economic adjustment policies and the environment: a case study for Brazil" (YOUNG, 1997), elaborated at the University College London, under Prof. David W. Pearce supervision.
} 


\section{THE DEFINITION OF INCOME}

The definition presented by Keynes (1973) provides a formal way to treat income incorporating the parameters which regulate the decisions concerning alternative ways of keeping assets. According to this definition, the entrepreneur's income from any productive activity $(E)$ in a time period $t$ is defined as the difference between the revenues obtained from the sale of final goods $(A)$, and the user cost $(U)$ and the amount paid for other production factors - labour, capital - $(F)$ involved in the production:

$$
E=A-U-F
$$

The user cost represents the total sacrifice the producer is willing to accept in order to carry on his or her production decision. It includes the current expenditures on non-labour intermediate inputs, and the expected losses in the asset stock due to production (including the value of the land).

Formally, user cost can be divided in two terms. The first term is constituted by the purchases from other producers $(A 1)$. The second term represents the capital losses occasioned by production, and it is defined by the difference between the value of the asset stock after the depreciation due to its use $(G)$, and the maximum value it could have if the assets were not used $\left(G^{\prime}\right)$, considering the maintenance and improvement costs necessary to achieve such a situation $\left(B^{\prime}\right)^{2}$.

$$
U=A 1+\left[\left(G^{\prime}-B^{\prime}\right)-G\right]
$$

Hence, equation (1) can be re-written by dividing income in two components. The first one $(E 1)$ represents the net revenues resulting from a certain production process. The second term (E2) represents the net changes in the asset stock, or investment, resulting from the same production process. For simplification, the former $(E 1)$ will be called the current revenue component, while the latter (E2) will be called the capital component.

$$
E=E 1+E 2
$$

\footnotetext{
2 The definition of asset stocks encompasses the stocks of final as well as intermediate goods, including raw materials.
} 
In (3),

$$
E 1=A-A 1-F
$$

and

$$
E 2=G-\left(G^{\prime}-B^{\prime}\right)
$$

The capital component establishes the link between present activity and the future: deciding the scale of production, the entrepreneur is also deciding how much of the capital stock will be preserved. Through this definition, expectations of capital appreciation or depreciation are incorporated in the calculation of income.

In other words, the income definition relates current production (given the stock of assets), represented by the current revenue component, to expectations for the future capacity to generate revenues from the same set of assets, represented by the capital component. Therefore, the decision to maximize income should refer not only to the immediate gains and losses resulting from the production decision: a proper calculation should also evaluate the long term consequences to the existing stock of assets.

The uncertainty about the future value of the asset is, therefore, part of the user cost. If there are concerns about the tenure of the asset, it means that there are lower expectations from the revenues one can expect in the medium or long term. The higher the uncertainty concerning the property rights relating to the asset, the less relevant the capital component becomes for the production decision. In a borderline situation where no property rights are defined, the capital component is completely irrelevant in the decision. This property, which can be associated with slash-and-burn situation, is fundamental for the application of any theoretical model to the problem of tropical deforestation.

\section{TROPICAL DEFORESTATION: BASIC FEATURES}

A simple model can be used to understand the link between land accumulation and deforestation in a quasi-open access frontier. Quasi-open access land refers to land where property rights are established only after economic occupation involving deforestation. The decision of land clearing is mainly motivated by the expectations of

profits from land accumulation, and land clearing is the mechanism for claiming 
property rights. Future sales are expected when property rights become wellestablished (in the main text, this is referred to in the discussion about the interaction between the 'new' and 'old' frontiers)'.

The model developed in this paper is inspired by similar attempts, particularly those by Southgate and Pearce (1988) and Southgate (1990). However, it introduces some unusual features distinct from the environmental economics modelling tradition. The most important ones refer to the Keynesian theoretical basis of such a model: its objective is not to determine an optimal set of prices, which would assure the most efficient use of the resource, but to examine how forest clearing decisions are affected by a set of policy related variables in the context of imperfect markets and uncertainty, where prices are given and expectations have exogenous elements in their formation.

The key element in the analysis is the profit maximization behaviour of individual farmers according to their own expectations, rather than a utility maximization exercise by a hypothetical (but non-existent) social planner. The deforestation process can be presented as a consequence of individually rational decisions, which, in aggregate, do not lead to a social maximum (because there is no mechanism, such as a social planner, to assure the automatic reconciliation of conflicting individual plans). This conceptual framework, distinct from the neoclassical perfect market approach, allows the theoretical treatment of market imperfections and speculative behaviour typical of the frontier economies, as described in Ozório de Almeida and Campari (1996) and Schneider (1994).

\section{SLASH-AND-BURN WITH NO LAND PROPERTY RIGHTS}

First, take the situation in which property rights are defined neither before, nor after land clearing (land surplus situation). This can be associated with traditional slashand-burn subsistence cultivation. Only the current component is relevant: there is no consideration for capital accumulation. Given the lack of investment, slash-and-burn cultivation is characterized by low productivity per unit of area. The only relevant costs are labour and transportation. There is no payment of interest or other transfers (taxes, direct subsidies, etc.).

\footnotetext{
3 An alternative way to look at the problem is to consider that the main economic motivation for land clearing is the concession of tax relief and credit subsidies to an extent that is proportional to the total area deforested (an issue frequently referred to in the Brazilian Amazon case).
} 
One important assumption is that farmers are price-takers, that is, agricultural production in the frontier is too small to affect the prices of agricultural goods, which reflect government policies and market conditions outside the frontier region. In a similar way, wages are given by government policy and labour market conditions outside the frontier. As discussed before, this cost should impute the opportunity cost of family labour which otherwise could have been paid to work outside the family plot. The other relevant source of costs is transportation, which is inversely related to the availability of roads.

Standard assumptions are considered for the output and input functions. Agricultural revenues per unit of land decrease if more land is cleared, but labour and transportation costs increase: the idea is that forested land is not homogeneous, and the first plot to be cleared is the one which presents higher expected net returns. Therefore, productivity and profitability decrease with the expansion of the cleared area.

This is a situation which disregards the capital component, and income equals the current component:

$$
E=E 1=A-W-R=A-C
$$

In (6), $A$ is the total revenue from agricultural production and $C$ is the total cost (sum of labour cost $W$ and transportation cost $R$ ).

$$
A=\bar{p}_{a} \cdot q_{a}
$$

In (7), $p_{a}$ is the (given) composed price of the aggregate agricultural output resulting from the cultivation after land clearing, including timber extracted before the forest is burned, and $q_{a}$ is the respective quantity produced.

$$
W=\bar{p}_{w} \cdot q_{w}
$$

In (8), $p_{w}$ is the (given) wage, and $q_{w}$ is the quantity of labour used.

$$
R=\bar{p}_{r} \cdot q_{r}
$$

In (9), $p_{r}$ is the (given) price of transportation, and $q_{r}$ is the quantity of transportation required.

Productivity declines with the expansion of cleared area but costs increase: 


$$
\begin{aligned}
& \frac{d q_{a}}{d l}>0 ; \frac{d^{2} q_{a}}{d l^{2}}<0 \\
& \frac{d q_{w}}{d l}>0 ; \frac{d^{2} q_{w}}{d l^{2}}<0 \\
& \frac{d q_{r}}{d l}>0 ; \frac{d^{2} q_{r}}{d l^{2}}<0
\end{aligned}
$$

These expressions result in (the primes represent first and second derivatives relative to deforested area):

$$
A^{\prime}>0, \mathrm{~A}^{\prime \prime}<0, C^{\prime}>0 \text { and } C^{\prime \prime}<0
$$

Since the time horizon is extremely short, future revenues and losses are not taken into account. The decision on how much land to clear is exclusively based on the maximization of the current component: land will be cleared up to the point when current costs exceed total current revenues. This is represented in Figure 1. The vertical axis represents the revenues and costs expected from the clearing and cultivation of forest land (the quality of land is variable, and the land with higher net revenues is cultivated first). The horizontal axis represents the amount of land $(L)$ the farmer decides to clear for agricultural use (i.e. $L$ is the amount of land where income is maximized). Since there is no concern over the capital component, total income exceeds the 'normal' income (the hypothetical income if the capital costs were included) in an amount equal to the depletion cost. Therefore, the lack of well defined property rights results is an extra incentive to clear land, corresponding to $L$ - $L^{*}$ hectares. 


\section{Figure 1 - Income maximization in the 'typical' slash-and-burn}

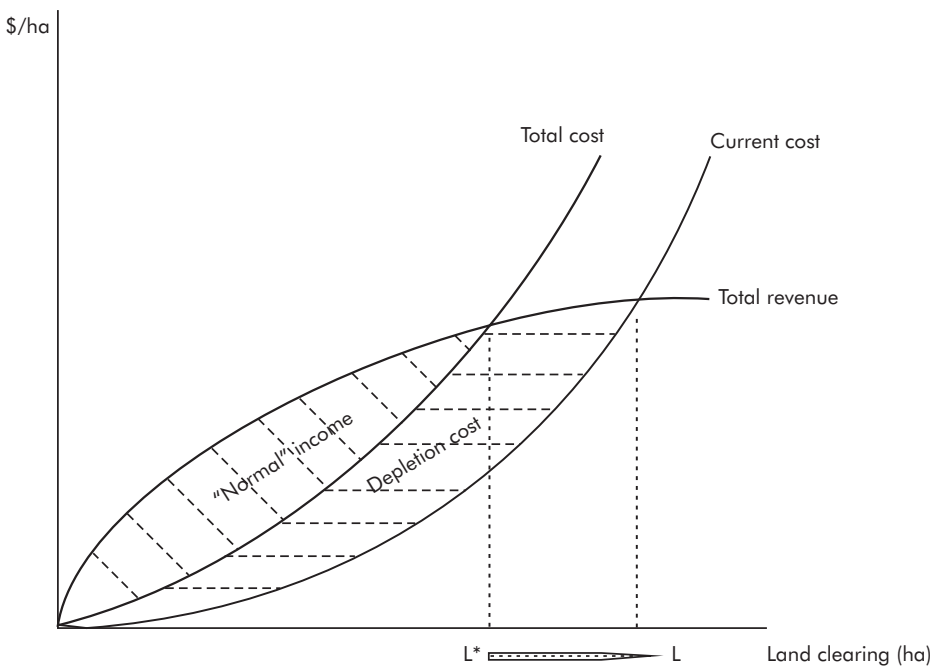

Source: Author's elaboration

After one or two years of cultivation, soil fertility falls considerably and the farmer moves to a new plot of forested land. The reason is that burning the biomass of the forest (nutrient mining) temporarily compensates for the lack of agricultural inputs or investment on land improvement required for the conservation of soil fertility - the biomass stores most of the nutrients, so burning the forest converts biomass nutrients to ash which can be 'mined' as fertilizer. Since the major cost is clearing the land, the farmer usually prefers to re-use a plot of land, which had been cleared before but was let to rest for a considerable period of time, with a secondary forest formation (capoeira) with enough biomass to allow a new cultivation cycle 4 . Thus, if the supply of (secondary) forest is sufficiently large to accommodate the demand for land every year, the system can be considered sustainable: there is no pressure to clear primary forest ${ }^{5}$.

4 The cost of clearing capoeiras is considered by Homma et al. (1994) as about half the cost of clearing primary forest.

5 The forest is 'sufficiently large' if $S>T . q^{*}$. $N$; where $S$ is total supply of forest land; $T$ is the minimum number of years required for the capoeira recover the critical amount of biomass to allow the return of cultivation (between 10 and 20 years in the Brazilian Amazon); $q^{*}$ is the annual requirement of land of an average farm (defined by the intersection of the marginal cost and marginal revenue functions); and $N$ is the total number of farmers. 
Economic policies may affect the level of deforestation by means of ${ }^{6}$ :

i) Increasing the revenue of agricultural production through higher agricultural prices. This corresponds to an upwards shift of the revenue curve and subsequent increase in the area cleared for cultivation (see Figure 2).

\section{Figure 2 - Increasing revenues in a typical slash-and-burn situation}

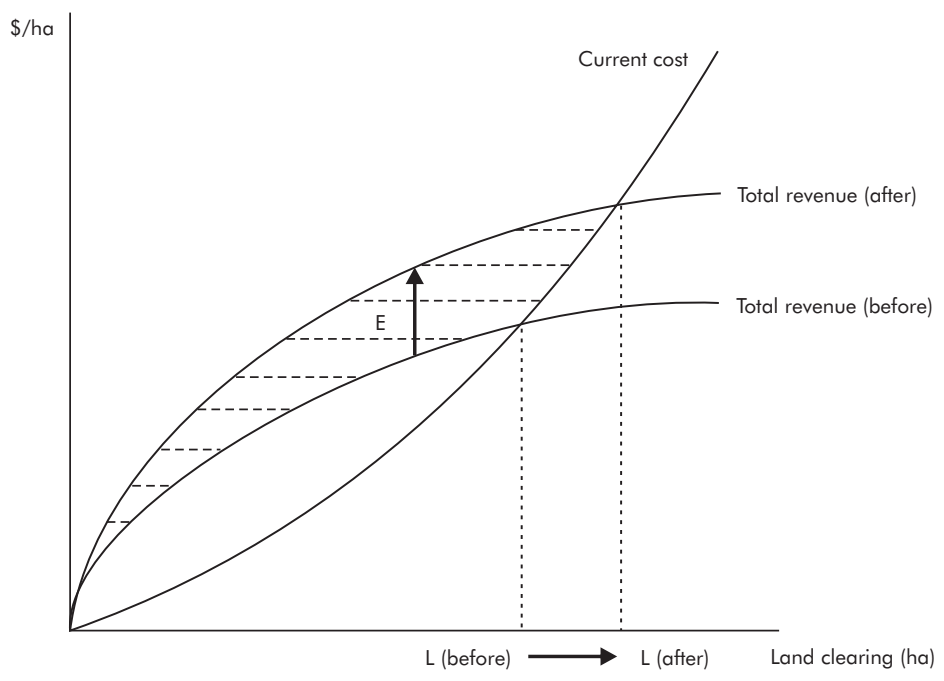

Source: Author's elaboration.

ii) Decreasing the cost of labour (for example, through measures which result in reducing wage levels in alternative labour markets, thus making people more interested in the option of moving to the frontier) or decreasing transportation costs (for example, opening new roads). This corresponds to a downwards shift of the current cost curve, resulting in an increase of the area cleared for cultivation (see Figure 3).

6 A formal proof is presented in the Appendix 1. 


\section{Figure 3 - Decreasing costs in a 'typical' slash-and-burn situation}

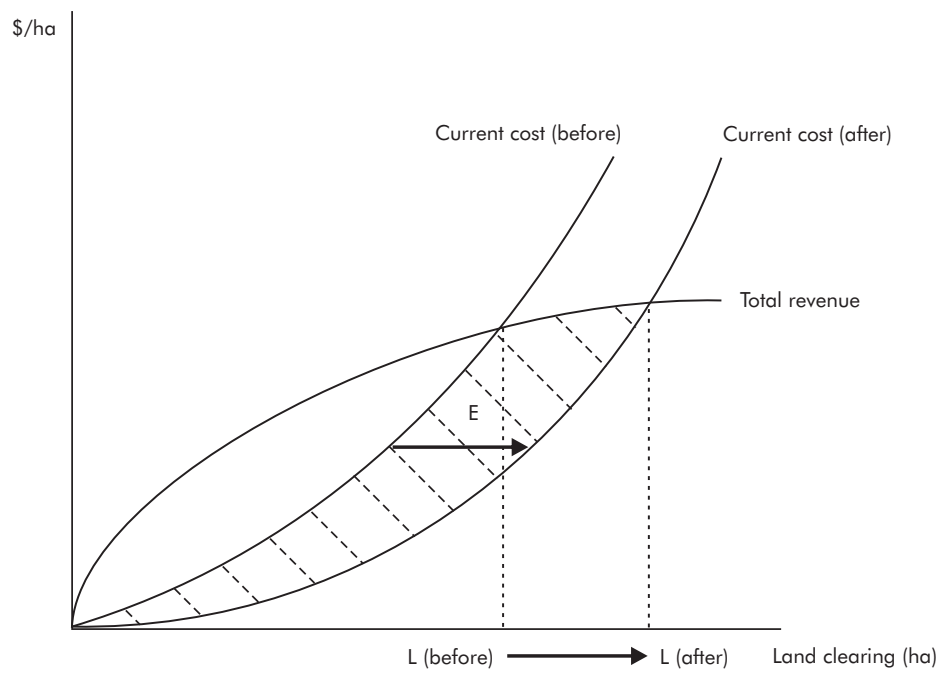

Source: Author's elaboration.

\section{INTRODUCING SELLING RIGHTS OVER LAND AFTER OCCUPATION}

An important change is introduced when settlers are allowed to sell land plots after a number of years of occupation. Therefore, the capital component should be incorporated in the income equation: the capital gains obtained from selling the land, net of the losses of timber and other natural resources which existed prior to deforestation.

In a conventional situation, it is expected that the value of an asset should decrease if used for production and no investment is carried out to compensate the subsequent depreciation. Under this approach the price of the land would have gone down if the natural resources were depleted by the clearing process necessary for cultivation of annual crops or ranching. However, the situation in the frontier is different because quasi-open access land is not in the market until it is occupied by the farmer. Hence, there is a capital gain for the settler which is the result of introducing 'new' land into the market. Therefore, in the decision of land clearing, the settler should consider the expected profit from selling the land as a capital gain in the calculation of income, even though the stock of natural resources embodied in the land may have fallen.

Conceptually what is suggested is that the value of the asset stock owned by the farmer after its use ( $G$, in the income definition) increases rather than decreases. This happens because land acquires a new quality - property rights - which could not be 
otherwise incorporated if the asset had not been used during production $\left(G^{\prime}\right)$. A situation of capital appreciation occurs since $(G)$ is higher than $\left(G^{\prime}\right)$. This capital appreciation is composed of the capital gain (corresponding to the value of land which has been officially granted) minus the cost of the sacrifice imposed by depleting the forest (the foregone revenues from timber, biomass and extractivism activities which were lost because the land was cleared). From the settlers' perspective, this depletion cost is usually smaller than the capital gain obtained from the grant of selling rights over the land, a quasi-rent obtained for the incorporation of the frontier land into a capitalist production framework ${ }^{7}$ : the asset component is equal to the latter minus the former.

In other words, the depletion of natural assets through the removal of the native vegetation is, from the settlers' perspective, an investment to assure land tenure rights, as if the consumption of the forest is required as an input for the 'production' of marketable land. The demand for land therefore derives from not only the net returns expected from productive activities but also from speculation over the gains from selling the land in the future. This is possible because better off farmers have higher expectations of future revenues, given their superior asset endowment and access to credit (OZÓRIO DE ALMEIDA and CAMPARI, 1996; SCHNEIDER, 1994).

Note that the settler usually claims plots of land larger than the area which has already been cleared. This extra land can be incorporated as a forest reserve inside the farm. Usually, the total area claimed is a multiple of the area which has been cleared. Therefore, the process of deforestation can follow two patterns: inside property (increasing the proportion of deforestation in plots which are already inside a farm with defined property rights) or outside property (encroachment which has not yet been claimed as private property).

\section{DUALITY AT THE FRONTIER}

The establishment of a land market at the frontier introduces a new agent in the model: the 'late' settler, who comes only after property rights are reasonably well defined (that is, after the 'early' settlers had already occupied the land). These farmers have a better endowment of capital and access to formal credit facilities, resulting in higher productivity per unit of area. The use of non-labour inputs and other land improvements allow agricultural production to increase without the need of clearing more forest areas (agricultural intensification).

\footnotetext{
7 In Marxist terms, this is described as 'primitive accumulation of capital'.
} 
However, the coming of this second generation of farmers is only possible after property rights are defined, since they need longer periods of time to maximize their production and they are not willing to face the uncertainty, requiring the establishment of some 'governmental functions' (using the expression of SCHNEIDER, 1994) before they establish themselves. Their production costs are higher, including the late settlers' own opportunity cost of labour, and they are not likely to be compensated by the low productivity of the traditional slash-and-burn cultivation.

Since the net present value of the income per unit of land expected by the late settlers is higher than the current value of the net revenues per unit of land expected by the early settler, the former is willing to pay more for the land than the latter would expect. Hence, the late settler will buy land from the early settler up to the point where the expected return equals the cost of intensifying production in the land already owned by the late settler.

A simple model describes this duality at the frontier. First, one should take into account the situation in the old frontier. The late settler is also subject to decreasing revenues and increasing costs per unit of area. The current cost function includes the payment of interests, because late settlers have access to credit facilities. The cost of credit is inversely related to the availability of official credit lines with subsidized interest, as it was the case in the Brazilian Amazon during the 1970s and 1980s. Since property rights have been established, the capital component is considered in the income calculation. This means that the depletion of natural resources should be considered in the estimation of futures revenues and costs. For simplification, it is assumed that the late settlers do not speculate with land prices, and therefore the capital losses and gains are represented in the stream of expected net revenues from agricultural use, discounted to the present ${ }^{8}$.

$$
\begin{gathered}
E_{L}=N P V\left(A_{L}-C_{L}\right)=\sum_{t=0}^{\infty} \frac{1}{(1+d)^{t}} \cdot\left(A_{L_{t}}-C_{L_{t}}\right) \\
A_{L}{ }^{\prime}>0, \mathrm{~A}_{L}{ }^{\prime \prime}<0, C_{L}{ }^{\prime}>0 \text { and } C_{L} "<0
\end{gathered}
$$

\footnotetext{
8 This step was taken in order to restrict the analysis to only two waves of migrants. In reality, the process is far more complex, and speculation with land prices is also an important reason for second, third or even later waves of farmers to acquire land in the frontier. The consequences of relaxing this assumption are discussed later.
} 
The demand for land at the old frontier created by the arrival of late settlers generates the expectation of profits for the early settlers if they move to the new frontier (that it, unoccupied terras devolutas), incorporating more land to be sold in the future. As discussed previously, the price of land at the new frontier is given by the conditions of production of the late settlers. The capital gain for 'acquiring' land in the new frontier is a fraction of the price of equivalent land in the old frontier':

$$
p_{l_{E}}=\alpha \cdot p_{l_{L}} \quad ; \quad 0<\alpha<1
$$

The income equation for the early settlers becomes:

$$
\begin{gathered}
A_{E^{\prime}}>0, A_{E} "<0, C_{E^{\prime}}>0 \text { and } C_{E} "<0 \\
E_{E}=A_{E}-C_{E}+\alpha \cdot p_{l_{L}}
\end{gathered}
$$

In (17) and (18), $A_{E}$ represents the (marginally decreasing) current revenues expected from agricultural activities and $C_{E}$ represents the (marginally increasing) costs of land clearing and cultivation.

For the early settlers, the future gain from selling land justifies the clearing of areas where they cannot expect positive net revenues from cultivation or other agricultural activities. Therefore, they will clear land up to the point where their marginal cost equals the sum of the marginal current revenue and the expected capital gain (meaning the fraction of the price of equivalent land in the old frontier), rather than solely the marginal current revenue. Since the former exceeds the later, deforestation is higher than in the previous situation where only the revenue component is considered in the income maximization problem (traditional slash-and-burn). It also explains why apparently uneconomic activities are carried out in the new frontier: indeed, the 'appearance' of using the land for production endorses the claim for property rights.

This is expressed in Figure 4. The right top quadrant describes the situation at the old frontier. The limit to land clearing in this region $(L($ of $))$ is given by the point where

\footnotetext{
9 Equivalent plots of land in the old and new frontier do not have the same price: if prices were the same, farmers would always prefer land in the old frontier because of the uncertainty concerning property rights in the new frontier. Therefore, the ratio between land prices in the new and old frontier expresses the degree of confidence in property rights: this ratio equals one only when confidence on tenure rights is identical in both regions.
} 
the marginal income expected from land clearing activities, expressed in present values (because property rights are well established in the old frontier), equals zero. The marginal income curve $\left(E^{\prime}(\mathrm{ls})\right)$ also determines the curve for the price of land in the region ( $p l(o f))$. As discussed before, the price of the land in the new frontier is a fraction of the price of equivalent land in the old frontier. This is represented by the equation in the top left quadrant.

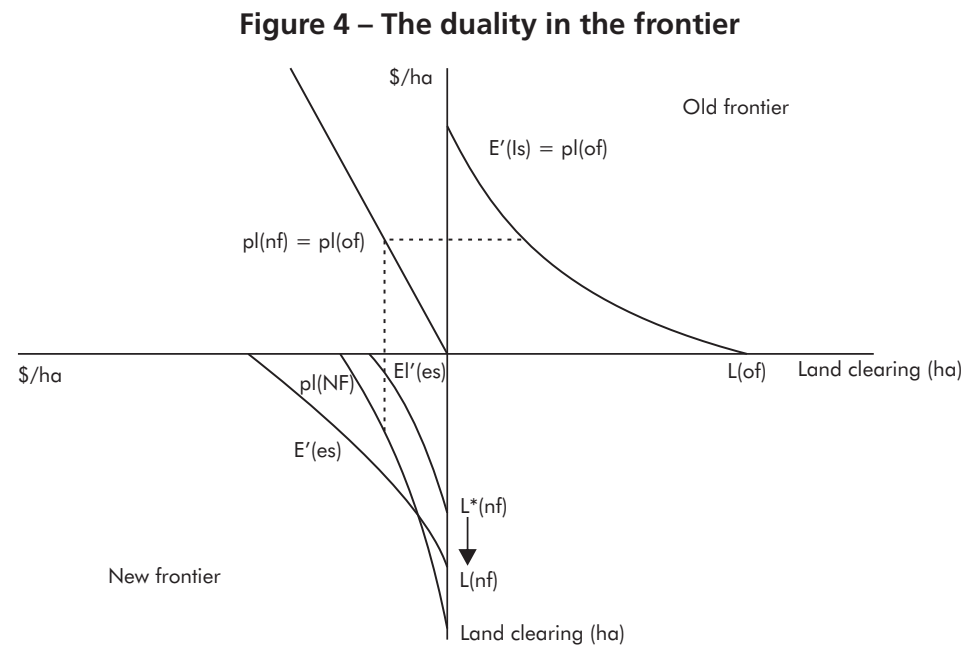

Source: Author's elaboration.

The bottom left quadrant represents the new frontier. The marginal income curve for the early settlers $\left(E^{\prime}(\mathrm{es})\right)$ is equal to the sum of the marginal current income $\left(E 1^{\prime}(\mathrm{es})\right)$ and the expected capital gains from acquiring land through land clearing (equals to the price of land in the new frontier, $\mathrm{pl}(\mathrm{nf})$ ). The consequence is that land clearing in the new frontier (at the point where $E^{\prime}(\mathrm{es})$ equals zero, or $L(\mathrm{nf})$ ) is higher than in the open situation $\left(L^{\star}(\mathrm{nf})\right.$, which is determined by $\left.E 1^{\prime}(\mathrm{es})\right)$ since the possibility of capital gains represent an extra incentive for land clearing.

Consideration of a 'dual' frontier allows a better understanding of the impacts of governmental policies to deforestation ${ }^{10}$ :

i) increasing agricultural prices increase the profitability of agricultural activities in both frontiers, therefore establishing an incentive to more deforestation in both regions (see Figure 5). Note that the higher profitability in the old frontier

${ }^{10}$ A formal proof of these results is presented in the Appendix 2. 
also increases land prices, fuelling the speculation motive for deforestation in the new frontier. A similar impact is expected if the policy results in the reduction of current costs for both early and late settlers (for example, an improvement of the road network in both areas).

Figure 5 - Increasing agricultural profitability in both frontiers

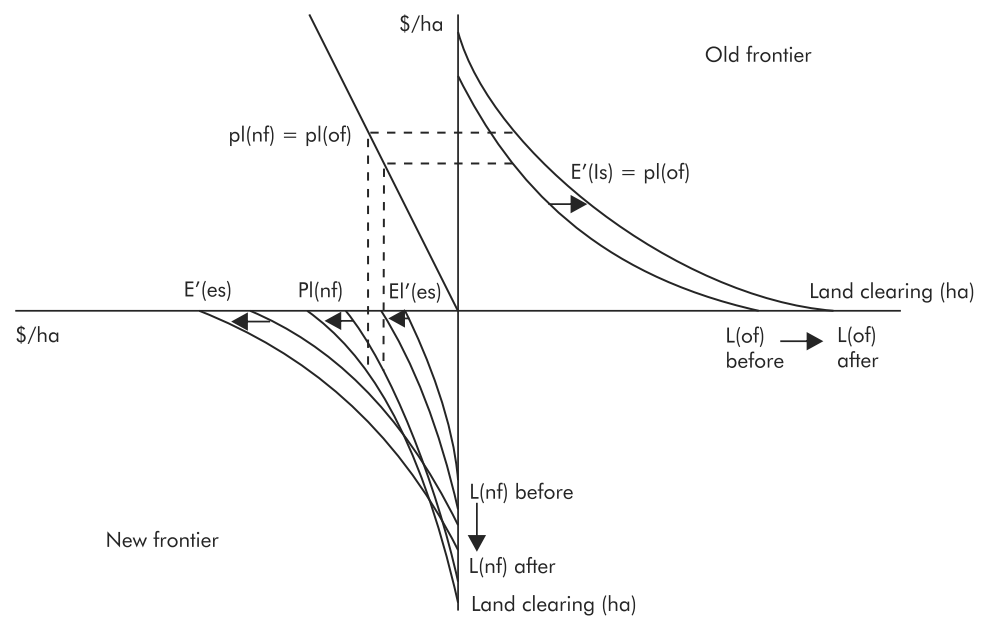

Source: Author's elaboration.

ii) The 'multiplier' effect of land price speculation as a motive for deforestation can be demonstrated with a simple exercise. Figure 6 describes the situation where only the old frontier has benefited directly from a specific policy: to use the previous example, consider that the road improvements did not affect the new frontier. Land prices in the old frontier increase because agricultural activities become more profitable. This also inflates land prices in the new frontier, increasing the expected gains from future land sale. The result is that deforestation increases in both regions, even though only the old frontier benefits directly from the policy change. Note that deforestation in both regions would increase with the removal of the simplistic assumption that late settlers do not speculate with land prices. In this more realistic situation, rising land prices in one region would start a wave of inflated prices in other areas which may not be directly connected to the original causes of the price increase. 
Figure 6 - Increasing agricultural profitability only in the old frontier

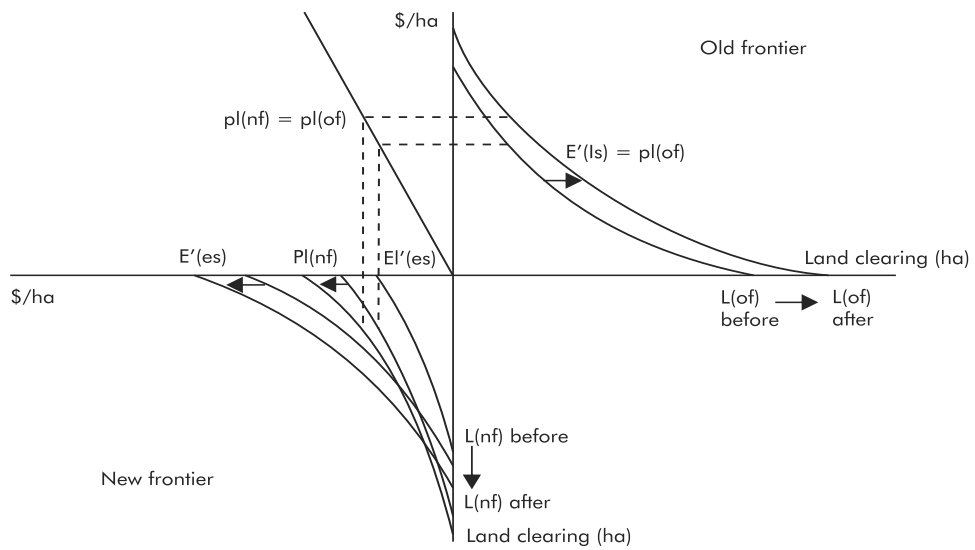

Source: Author's elaboration.

iii) It is clear from this analysis that reducing speculation would bring positive impacts in the control of deforestation. Figure 7 shows a situation where a corrective policy is introduced to deter speculation in the new frontier (increasing taxes on land transfer, stopping land concessions to large farmers, imposition of a ban on re-selling land distributed to small farmers, improving the control against encroachment on public and indigenous territories, or reducing the uncertainty on capital markets thus creating a safe alternative to investment in real assets such as land). This has the effect of decreasing the expected capital gains from land clearing, reducing the profitability of deforestation.

Figure 7 - Reducing the speculation motive for land clearing

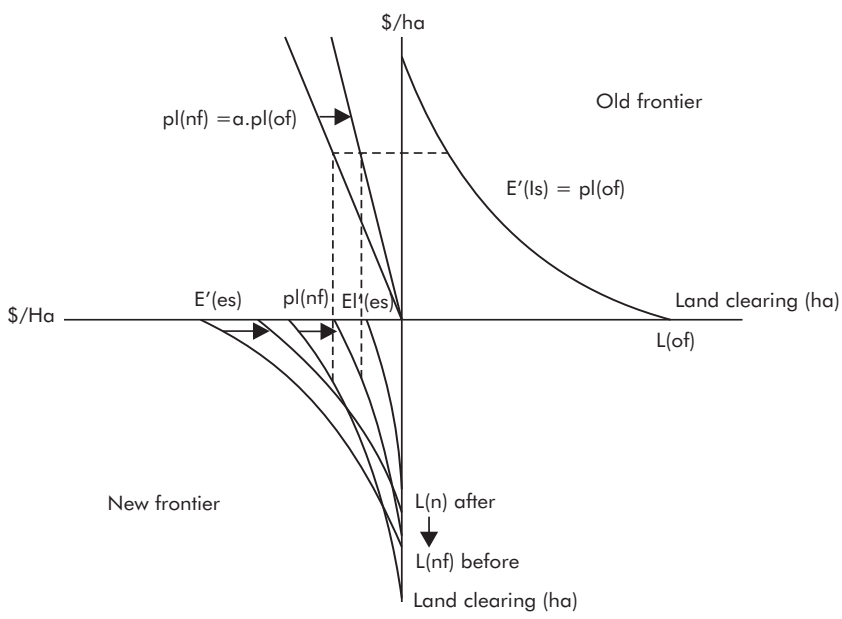

Source: Author's elaboration. 


\section{INCOME EFFECTS}

One issue not taken into consideration in the analysis above refers to income effects. Deforestation in the new frontier is likely to be indirectly encouraged by the increase in the total income of late settlers. Nevertheless, this income effect should be weighed against the risk aversion of late settlers, who may prefer to intensify production in already owned land rather than risk a move to remote and relatively unsafe land in the new frontier. A similar issue refers to the flexibility to move resources between the old and new frontiers. If there are clear signals that the benefits introduced in the old frontier (infrastructure improvement, 'government functions') will not be expanded to the new frontier, there will be less interest in investing in the new frontier.

If the proper institutional framework is established to avoid the 'speculation multiplier', the demand for land in the new frontier becomes inversely related to the cost of agricultural intensification in the old frontier. This is the argument used in favour of improving infrastructure and living conditions for the settlers already established in the frontier: better conditions in the area they already occupy would represent an incentive not to move further into the new frontier. There would be an increase in deforestation in the areas already occupied, but it would stop further advance of the agricultural frontier.

\section{CONCLUDING REMARKS}

Environmental consequences of macroeconomic policies are usually not considered in the decision making process. However, if sustainability is incorporated in the development debate, these economy-environment links can no more be ignored. The objective of the theoretical model presented in this paper is to provide some insights to understand the connections between economic policies and the problem of tropical deforestation. It is also an open invitation for heterodox economists to be more audacious in the use of Keynes' General Theory ideas in non conventional areas, such as environmental economics.

\section{REFERENCES}

HARTWICK, J. M. Deforestation and national accounting. Environmental and Resource Economics, v. 2, p. 513-521, 1992.

HOMMA, A. K. O. et al. Redução dos desmatamentos na Amazônia: política agrícola ou ambiental? In: INTERNATIONAL CONFERENCE ON SYSTEM INTEGRATION, 3., São Paulo, 1994. 
KEYNES, J. M. The collected writings of John Maynard Keynes. Volume VII. The general theory of employment, interest and money. Cambridge: Macmillan/Cambridge University Press, 1973.

MAHAR, D.; SCHNEIDER, R. "Incentives for tropical deforestation: some examples from Latin America”. In: BROWN, K.; PEARCE, D. (Eds.). The causes of tropical deforestation. London: University College London Press, 1994.

OZÓRIO DE ALMEIDA, A. L.; CAMPARI, J. Sustainable settlement in the Amazon. New York: Oxford University Press, 1996.

SCHNEIDER, R. Government and the economy on the Amazon frontier. LAC Regional Studies Program Report, n. 34. Washington, D.C.: The World Bank, 1994.

SOUTHGATE, D. The causes of land degradation along "spontaneously" expanding agricultural frontiers in the Third World. Land Economics, v. 66, n. 1, p. 93-101, 1990.

SOUTHGATE, D.; PEARCE, D. W. Agricultural colonization and environmental degradation in frontier developing economies. Working Paper, World Bank, Environment Department, n. 9, 1988.

YOUNG, C. E. F. Economic adjustment policies and the environment: a case study for Brazil. $\mathrm{PhD}$ Dissertation - University College London, London, 1997.

YOUNG, C. E. F. "Public policies and deforestation in the Brazilian Amazon". In: SEROA DA MOTTA, R. (Ed.). Environmental economics and policy making in developing countries. Cheltenham: Edward Elgar, 2001, p. 140-155.

\section{APPENDIX 1}

Consider the income equation for the settler (from equations 6 to 9):

$$
E=\overline{p_{a}} \cdot q_{a}-\overline{p_{w}} \cdot q_{w}-\overline{p_{r}} \cdot q_{r}
$$

Income is maximised at the point in which marginal revenue equals marginal costs (the primes represent first derivatives relative to deforested areas), i.e.:

$$
\overline{p_{a}} \cdot q^{\prime}{ }_{a}=\overline{p_{w}} \cdot q^{\prime}{ }_{w}+\overline{p_{r}} \cdot q_{r}^{\prime}
$$

Equation (20) can be expressed as:

$$
\overline{p_{a}}=\overline{p_{w}} \cdot \frac{q_{w}^{\prime}}{q_{a}^{\prime}}+\overline{p_{r}} \cdot \frac{q_{r}^{\prime}}{q_{a}^{\prime}}
$$

If there is a government intervention to increase agricultural output prices in time $t=1$ relative to time $\mathrm{t}=0$ (labour and transportation costs remaining constant), this implies: 


$$
\overline{p_{a_{1}}}>\overline{p_{a_{0}}} \Rightarrow \overline{p_{w}} \cdot \frac{q_{w_{1}}^{\prime}}{q_{a_{1}}^{\prime}}+\overline{p_{r}} \cdot \frac{q_{r_{1}}^{\prime}}{q_{a_{1}}^{\prime}}>\overline{p_{w}} \cdot \frac{q_{w_{0}}^{\prime}}{q_{a_{0}}^{\prime}}+\overline{p_{r}} \cdot \frac{q_{r_{0}}^{\prime}}{q_{a_{0}}^{\prime}}
$$

This is only possible if either $q_{a 1}{ }^{\prime}<q_{a 0}{ }^{\prime}, q_{w 1}{ }^{\prime}>q_{w 0}{ }^{\prime}$, or $q_{r 1}{ }^{\prime}>q_{r 0}{ }^{\prime}$. Since equations 10 to 13 establish diminishing agricultural returns $\left(q_{a}{ }^{\prime \prime}<0\right)$ and increasing production costs $\left(q_{w}>0\right.$ and $\left.q_{r}>0\right)$, these results show that the new income maximisation point occurs in a situation of increased cultivation in deforested areas $\left(l_{1}>l_{0}\right)$.

In other words, higher agricultural prices mean that land clearing for cultivation becomes feasible in areas that were not profitable previously.

An analogous situation can be obtained if government intervention results in decreasing production costs through lower wages $\left(p_{w 1}<p_{w 1}\right)$ or smaller transportation costs $\left(p_{r 1}<p_{r 1}\right)$.

\section{APPENDIX 2}

Equation (14) establishes that the income of late settlers in the old frontier (at time $t=0)$ is determined by the expected stream of net revenues from agricultural use of this land, discounted to the present:

$$
E_{L_{0}}=\sum_{t=0}^{\infty} \frac{1}{(1+d)^{t}} \cdot\left(\overline{p_{a_{L_{t}}}} \cdot q_{a_{L_{t}}}-\overline{p_{w_{L_{t}}}} \cdot q_{w_{L_{t}}}-\overline{p_{r_{L_{t}}}} \cdot q_{r_{L_{t}}}-\overline{p_{c_{L_{t}}}} \cdot q_{c_{L_{t}}}\right)
$$

In (23), $p_{c L}$ represents the (given) price of credit and $q_{c L}$ is the quantity of credit used by the late farmers (early settlers do not have access to credit).

Given their expectations of future (given) prices, late settlers aim to maximise their income, cultivating land up to the point where marginal revenue equals marginal costs (both expressed in present value terms):

$$
P V_{0}^{\prime}\left(\overline{p_{a_{L}}} \cdot q_{a_{L}}\right)=P V_{0}^{\prime}\left(\overline{p_{w_{L}}} \cdot q_{w_{L}}\right)+P V_{0}^{\prime}\left(\overline{p_{r_{L}}} \cdot q_{r_{L}}\right)+P V_{0}^{\prime}\left(\overline{p_{c_{L}}} \cdot q_{c_{L}}\right)
$$

More productive or well located parcels of land are cleared before less fertile or remote parcels. Therefore, agriculture in the old frontier has decreasing returns and increasing production costs:

$$
P V^{\prime \prime}\left(\overline{p_{a_{L}}} \cdot q_{a_{L}}\right)<0, P V^{\prime \prime}\left(\overline{p_{w_{L}}} \cdot q_{w_{L}}\right)>0, P V^{\prime \prime}\left(\overline{p_{r_{L}}} \cdot q_{r_{L}}\right)>0 \text { and } P V^{\prime \prime}\left(\overline{p_{c_{L}}} \cdot q_{c_{L}}\right)>0
$$


Policy interventions which increase agricultural prices or reduce farmers' costs (reduction of labour, transportation or credit costs) raise the profitability of agriculture in the old frontier, therefore encouraging deforestation of land which was previously unfeasible.

For example, if the government provides subsidized credit to farmers in the old frontier, there is a reduction of the credit cost function:

$$
P V_{1}^{\prime}\left(P_{c L} \cdot q_{c L}\right)<P V_{0}^{\prime}\left(\overline{p_{c_{L}}} \cdot q_{c_{L}}\right)
$$

Applying inequality (26) to the income maximisation equation (24):

$$
P V_{1}^{\prime}\left(\overline{p_{a_{L}}} \cdot q_{a_{L}}\right)-P V_{1}^{\prime}\left(\overline{p_{w_{L}}} \cdot q_{w_{L}}\right)-P V_{1}^{\prime}\left(\overline{p_{r_{L}}} \cdot q_{r_{L}}\right)<P V_{0}^{\prime}\left(\overline{p_{a_{L}}} \cdot q_{a_{L}}\right)-P V_{0}^{\prime}\left(\overline{p_{w_{L}}} \cdot q_{w_{L}}\right)-P V_{0}^{\prime}\left(\overline{p_{r_{L}}} \cdot q_{r_{L}}\right)
$$

Since prices are exogenously determined, the second derivatives in (25) imply that inequality (27) can only be satisfied if there is an expansion of deforested area for cultivation $\left(l_{L 1}>l_{L 0}\right)$.

Note that it is not necessary that agricultural credit actually increases to achieve the same result: if there is a widespread expectation that credit costs will be lowered, than the present value of (expected) future credit costs will be reduced. This point is particularly important in the explanation of forest clearing in areas where land price speculation was widespread because of the expectation of road building, an issue frequently addressed in the literature (for example, see MAHAR and SCHNEIDER, 1994; OZORIO DE ALMEIDA and CAMPARI, 1994).

Land prices in the old frontier are an indication to early settlers of how much they can profit if they are successful in their claims for property rights over the land they are occupying. This possibility of capital gains for 'acquiring' land in the new frontier through occupation represents an addition of revenues in the early settlers income equation. Equation (16) determines this expected capital gain as a fraction of the price of an equivalent plot of land in the old frontier:

$$
E_{E}=\overline{p_{a}} \cdot q_{a_{E}}-\overline{p_{w}} \cdot q_{w_{E}}-\overline{p_{r}} \cdot q_{r_{E}}+\alpha \cdot p_{l_{L}} \cdot q_{l_{L}}
$$

The income maximisation point is determined by ${ }^{11}$ :

11 The partial derivative of the quantity of land relative to itself equals one. 


$$
\overline{p_{a}} \cdot q_{a_{E}}^{\prime}+\alpha \cdot p_{l_{L}}=\overline{p_{w}} \cdot q_{w_{E}}^{\prime}+\overline{p_{r}} \cdot q_{r_{E}}^{\prime}
$$

Since the price of land in the old frontier is determined by the expected return of agricultural production (equation 23), any change in the profitability of the late settlers' activities will affect the demand for land in the new frontier. In the previous example of subsidised credit (which only late settlers have access to), the higher profitability of production increases the price of land in the old frontier and, consequently, the expectation of capital gains through occupying land in the new frontier. This represents a shift of the income maximising point:

$$
p_{l_{L_{1}}}>p_{l_{L_{0}}} \Rightarrow\left(\overline{p_{a}} \cdot q_{a_{E_{1}}}^{\prime}-\overline{p_{w}} \cdot q_{w_{E_{1}}}^{\prime}-\overline{p_{r}} \cdot q_{r_{E_{1}}}^{\prime}\right)<\left(\overline{p_{a}} \cdot q_{a_{E_{0}}}^{\prime}-\overline{p_{w}} \cdot q_{w_{E_{0}}}^{\prime}-\overline{p_{r}} \cdot q_{r_{E_{0}}}^{\prime}\right)
$$

As already discussed in Appendix 1, the inequality (30) is only satisfied if there is an increase in the amount of land cleared in the new frontier $\left(l_{E 1}>l_{E 0}\right)$ - income maximisation shifts to a point where marginal returns of agricultural production are lower and marginal costs are higher than in a situation where there are no capital gains from 'producing' land property rights.

If there is a retract in the government policy of allowing the sale of land distributed to early settlers, there will be a reduction in the speculative motive for clearing land. This would be equivalent to a reduction of the land speculation factor:

$$
\alpha_{1}<\alpha_{0} \Rightarrow\left(\overline{p_{a}} \cdot q_{a_{E_{1}}}^{\prime}-\overline{p_{w}} \cdot q_{w_{E_{1}}}^{\prime}-\overline{p_{r}} \cdot q_{r_{E_{1}}}^{\prime}\right)>\left(\overline{p_{a}} \cdot q_{a_{E_{0}}}^{\prime}-\overline{p_{w}} \cdot q_{w_{E_{0}}}^{\prime}-\overline{p_{r}} \cdot q_{r_{E_{0}}}^{\prime}\right)
$$

In that case, there will be a reduction in the demand for land in the new frontier since the income maximisation point shifts to a situation of higher marginal agricultural returns and lower marginal costs $\left(l_{E 1}<l_{E 0}\right)$. 